\title{
KONSTRUKSI BERITA KONFLIK PASCA BENCANA ALAM PADA HARIAN KOMPAS
}

\author{
Dian Muslimah \\ Dosen Sosiologi Fakultas Sosial dan Ilmu Politik Universitas Bengkulu
}

\begin{abstract}
Natural disasters often lead to social change, and the changes of structural society often lead to post-disaster conflicts in the community. When a natural disaster occurs, the mass media became one of the main elements that preach it to the outside world through a text message. While the news is the result of social construction that always involving views, ideologies and values. Construction performed by mass media does not take place in an empty space, but it is loaded with interests especially for the news of conflict, because it contains a high value news.

This study aimed to determine the focus on post disaster situations on Kompas news, and how Kompas taking up the post-conflicts on Padang earthquake within community through text message construction. This study is focused on the news text in the Kompas Daily that contain post earthquake conflict during October, 2009, and will be analyzed using critical discourse analysis of Teun Van Dijk's three levels of analysis methods. Seen from the analysis result of post-disaster conflict news text that occurred in Padang, the post- disaster conflict news had conducted by Kompas daily with a great caution. News themes of conflict that raised were not presented the opinion of both parties who are in conflict in the same text news. From the social analysis of this research, conflicts regarding to natural disaster relief as happened in West Sumatra were included in the conflict caused by differences in the aspirations between parties, which led to negative attitudes and perceptions to other party.

While the result of social cognition analysis to Kompas, found that past experiences lead Kompas applying style crab journalism that being cautious, especially in conflict review. Kompas Daily also apply transcendental humanism principles to make it accepted by all parties. Moreover, the presence of Standardization Language team (BP) that standardize the language, makes the language style used by Kompas become more delicate and polite.

In the earthquake disaster that occurred in Padang, the conflict was happened vertically, between the community and government caused by the unequal distribution of aid. By the factors, conflicts are often caused by the process of social change are not equally experienced by people in the community structure, the social changes experiencing by the post-disaster community are caused by unexpected pressure beyond human capability as well as the factor of interest (of the government/ authorities) which further leads to survival instinct. But apparently behind the process of social change that led to conflict, post-disaster conflict was caused by the society attempts to get back the means of production due to the changing mode of production caused by natural
\end{abstract}


disasters. This effort makes a vertical conflict between the government as a resource owners and the community as a group that does not have the resources, which leads to collective action such as protests against the policies of aid distribution that are deemed unfair.

Keywords : Disasters, Conflicts, Critical Discourse Analysis

\section{PENDAHULUAN}

Bencana seolah tak pernah berhenti melanda Indonesia. Terjadinya berbagai bencana yang masif dan beruntun di seluruh wilayah Indonesia, membawa dampak negatif terhadap tingkat kesejahteraan maupun kesenjangan sosial ekonomi masyarakat. Salah satu bencana alam yang kerap menyapa Indonesia adalah bencana alam gempa bumi atau yang lebih sering disebut gempa saja. Menurut Sukandar Rumidi (2010), gempa merupakan sentakan asli pada kulit bumi sebagai gejala penggiringan aktivitas tektonik maupun vulkanik dan kadang-kadang runtuhan secara lokal.

Secara histografi, Indonesia merupakan wilayah langganan bencana alam gempa bumi dan tsunami. Wilayah Indonesia dikepung oleh lempeng Eurasia, lempeng Indo-Australia, dan lempeng Pasifik. Sewaktu-waktu lempeng ini akan bergeser patah menimbulkan gempa bumi. Sejarah gempa di Indonesia cukup panjang.
Indonesia tercatat sebagai negara dengan jumlah gempa bumi dengan kekuatan diatas 4 pada skala richter yang terbanyak, yaitu rata-rata lebih dari 400 kali per tahun. Salah satu daerah yang sering menjadi menjadi langganan gempa bumi adalah pulau Sumatra. Pulau Sumatra termasuk dalam jalur patahan aktif yang paling sering menjadi pusat gempa. Tercatat sejak lima tahun terakhir sebelum jalur barat pulau Sumatra telah mengalami sepuluh kali gempa bumi dengan skala diatas 7 skala richter, yaitu pada Desember 2004, Maret dan April 2005, Agustus 2007, 12 dan 13 September 2007, Oktober 2007, 20 dan 25 Februari 2008 serta 2 dan 30 September 2009 (Data sekunder diolah dari berita-berita Kompas).

Ketika sebuah bencana alam terjadi, struktur masyarakat yang ada di dalam wilayah yang terkena bencana alam pun akan berubah. Terjadi perubahan sosial dan budaya akibat dari rusaknya sistem lingkungan fisik dan lingkungan sosial. Fungsi-fungsi sosial 
yang rusak dapat memberikan implikasi besar dalam jangka waktu yang lama pada tatanan kehidupan sosial masyarakat pasca bencana alam. Perbedaan dalam menyikapi situasi pasca bencana bagi setiap masyarakat berbeda-beda. Terutama pada prosesproses struktural yang memungkinkan masyarakat untuk mengembangkan suatu proses adaptasi terhadap lingkungan sosial yang berubah yang meliputi seluruh lapisan masyarakat. Bencana mendorong budaya dan masyarakat suatu lingkungan untuk mengalami transformasi.

Hofmann dan Oliver-Smith (1999) menyatakan bahaya bencana alam dapat menyebabkan perubahan organisasi dan struktur masyarakat, serta mempengaruhi sistem religi, ekonomipolitik, kekerabatan dan asosiasi. Bencana juga mempengaruhi perubahan teknologi, sikap dan pengelolaan lingkungan serta konstruksi fisik dan ekologi kultural. Masyarakat pasca bencana alam mengalami masalah yang beragam karena bencana itu sendiri juga beragam, dihasilkan dari berbagai kekuatan dan memproduksi berbagai dampak dalam skala dan kronologi yang berbeda-beda.
Ketika bencana alam terjadi, media massa menjadi salah satu unsur utama yang mengabarkannya kepada dunia luar melalui teks beritanya. Sebagai contoh ketika terjadi bencana gempa Padang 2009. Bencana yang menelan cukup banyak korban jiwa dan benda ini memiliki kekuatan 7,6 skala richter dan terjadi di lepas pantai Sumatra Barat pada pukul 17:16:10 WIB tanggal 30 September 2009. Gempa ini terjadi di sekitar $50 \mathrm{~km}$ barat laut Kota Padang. Gempa menyebabkan kerusakan parah di beberapa wilayah di Sumatra Barat seperti Kabupaten Padang Pariaman, Kota Padang, Kabupaten Pesisir Selatan, Kota Pariaman, Kota Bukittinggi, Kota Padang Panjang, Kabupaten Agam, Kota Solok, dan Kabupaten Pasaman Barat. Menurut data Satkorlak PB, sedikitnya 1.117 orang tewas akibat gempa ini yang tersebar di 3 kota dan 4 kabupaten di Sumatra Barat. Korban luka berat mencapai 1.214 orang, luka ringan 1.688 orang, korban hilang 1 orang. Sedangkan 135.448 rumah rusak berat, 65.380 rumah rusak sedang, dan 78.604 rumah rusak ringan (data sekunder diolah dari berita-berita Kompas).

Gempa yang terjadi pada sore hari ini ramai mengisi kolom-kolom 
berita pada berbagai media massa baik cetak maupun elektronik. Salah satunya adalah Harian Kompas. Secara rutin, setiap harinya Harian Kompas menyajikan berita dan perkembangan situasi pasca gempa terutama dalam bulan-bulan awal (lebih intensif di bulan pertama) setelah kejadian gempa. Berita mengenai gempa bumi nyaris mengisi hampir seluruh halaman harian Kompas.

Berita adalah hasil dari konstruksi sosial yang selalu melibatkan pandangan, ideologi dan nilai-nilai. Berger dan Luckman menyebutkan bahwa konstruksi yang dilakukan media massa tidak berlangsung dalam ruang hampa, namun sarat dengan kepentingan-kepentingan seperti ungkapan McLuhan, bahwa media adalah pesan (medium is message), menunjukkan bahwa media tidak bebas nilai. Media membawa kepentingan (Altheide, 1985). Bagaimana realitas itu dijadikan berita sangat bergantung pada bagaimana fakta itu dipahami dan dimaknai.

Dalam suatu kejadian gempa bumi, media terkadang melakukan peliputan yang lebih dititik beratkan pada kepentingan tertentu. Perubahan struktur masyarakat dan dampak sosial yang ditimbulkan suatu bencana alam menjadi bahan pemberitaan yang menarik untuk disajikan. Konflik dalam masyarakat seringkali muncul ketika suatu struktur masyarakat mendapat tekanan seperti yang diungkapkan oleh Setyarto (2012) bahwa bencana alam letusan gunung merapi telah menimbulkan konflik horizontal dan vertikal di masyarakat. Senada dengan itu, Millah (2008) juga menyatakan bahwa bantuan rekonstruksi bencana menimbulkan konflik vertikal dalam masyarakat. Dalam jurnalisme, mengangkat peristiwa sosial yang menimbulkan konflik menjadi suatu berita adalah suatu konstruksi yang lazim dilakukan karena konflik merupakan realitas sosial yang mengandung nilai berita sehingga mampu menarik audiens. Karena itu seringkali peristiwa bencana alam yang menimbulkan konflik diangkat dalam liputan media massa sebagai salah satu daya tarik berita dan dikonstruksikan sedemikian rupa yang dipengaruhi oleh sistem kekuasaan dimana media tersebut berada.

Atas dasar pemaparan diatas, penelitian ini berusaha menjawab dua pertanyaan sebagai berikut: Pertama, bagaimana fokus pemberitaan Harian Kompas terhadap situasi konflik pasca 
bencana alam? Kedua, bagaimana Harian Kompas mengulas konflik yang terjadi pada masyarakat pasca bencana alam gempa bumi di Padang melalui konstruksi teks beritanya?

\section{METODE PENELITIAN}

Penelitian ini memakai metode analisis wacana (discourse analysis). Istilah analisis wacana adalah istilah umum yang dipakai dalam banyak disiplin ilmu dan dengan berbagai pengertian, titik singgungnya adalah analisis wacana berhubungan dengan studi mengenai pemakaian bahasa, di samping itu, wacana bisa dipakai sebagai pernyataan baik dalam bentuk lisan maupun tertulis yang tidak netral. Hal ini dikarenakan setiap pernyataan itu selalu berisi kepentingan-kepentingan tertentu yang disampaikan oleh pihak penutur dalam konteks yang lebih luas, dengan demikian wacana selalu terikat dengan konteks sosial dan konteks sejarah. Maka untuk menyingkap makna yang tersembunyi serta berada di bawah permukaan dapat dilakukan dengan menggunakan metode seperti semiotika, analisis wacana atau hermeneutika.

Penelitian ini menggunakan pendekatan penelitian kualitatif dengan paradigma kritis dan dipaparkan dengan cara deskriptif-analitis yang dikembangkan Teun A Van Dik. Maka ada beberapa pendekatan yang ditawarkan dari analisis wacana ini. Salah satunya yang digunakan dalam penelitian ini adalah pendekatan kognisi sosial (socio cognitive approach). Van Dijk melihat wacana sebagai struktur tiga dimensi yang terdiri dari teks, kognisi sosial dan konteks sosial. Dalam dimensi teks, yang diteliti adalah struktur dari teks. Kognisi sosial merupakan dimensi untuk menjelaskan bagaimana suatu teks diproduksi oleh individu atau kelompok pembuat teks dalam hal ini wartawan Harian Kompas dan dewan redaksi. Cara memandang suatu realitas sosial melahirkan teks tertentu. Konteks sosial melihat bagaimana suatu teks dihubungkan lebih jauh dengan struktur sosial dan pengetahuan yang berkembang dalam masyarakat atas suatu wacana.

Penelitian ini memusatkan objek kajiannya pada teks pemberitaan konflik pasca bencana alam gempa bumi dalam harian Kompas edisi bulan Oktober, tahun 2009. Sumber data dalam penelitian ini adalah eksemplar Harian Kompas edisi bulan Oktober tahun 2009 yang menyajikan berita konflik pasca bencana alam. Pertimbangan 
penggunaan sumber data karena bencana gempa bumi yang melanda Sumatra barat dan sekitarnya terjadi pada tanggal 30 September 2009. Maka Harian Kompas yang terbit pada edisi bulan Oktober 2009 diperkirakan menyajikan laporan mengenai situasi pasca gempa yang komprehensif.

\section{HASIL DAN PEMBAHASAN}

Secara bisnis media, bencana alam adalah sebuah "bad news, but good news" karena mempunyai nilai jual yang tinggi, terlebih lagi jika skala bencana yang terjadi besar dan mengakibatkan korban jiwa yang banyak. Saat terjadi bencana alam, media-media di Indonesia menunjukkan euforia dalam memberitakan dan mengeksploitasi berita secara terus menerus. Sangat disayangkan karena justru dalam setiap kasus bencana alam yang terjadi masyarakat menggantungkan sumber informasi tentang bencana dari media terlebih jika dilokasi bencana masih terdapat kerabat dan kenalan.

Dalam setiap bencana alam yang terjadi, setiap media akan berlombalomba untuk bisa melaporkan paling duluan secara eksklusif. Tidak salah kalau kiranya media massa tertarik untuk menjadi yang pertama dalam melaporkan sebuah kejadian bencana karena dalam suatu kejadian bencana alam paling sedikit terdapat tiga aspek menarik untuk diangkat, pertama besaran bencana menurut skala perhitungan internasional, kedua, kehancuran dan kerugian material serta ketiga, jumlah manusia yang menjadi korban dalam bencana tersebut.

$$
\text { Prinsip-prinsip penting dalam }
$$
jurnalisme bencana seperti akurasi, humanisme, komitmen menuju rehabilitasi serta kontrol dan advokasi (Amirudin, Suara Merdeka 26 Januari 2007) seringkali terabaikan ketika para jurnalis hanya berpikiran untuk menyampaikan informasi sebanyakbanyaknya. Dampak publikasi yang berulang-ulang itu melahirkan masyarakat yang mengidap sindrom compassion fatigue, atau bebal dan tak acuh terhadap berita bencana. Kisahkisah sarat air mata dan darah menjadi berita baik bagi media. Alhasil korban bencana menjadi korban media, mereka menjadi obyek peliputan paling favorit.

Nazaruddin (2007) menyatakan rendahnya kualitas jurnalisme bencana karena terdapat banyak kelemahan dalam praktik penulisan jurnalisme bencana. Hal ini dipengaruhi rendahnya ketrampilan jurnalistik wartawan 
Indonesia dalam meliputi bencana dan faktor ideologi kapital-komersial dalam setiap aktifitas media dan jurnalistik. Bersamaan dengan hal tersebut, Nazaruddin (2007) mengajukan agenda penelitian discourse analysis dengan tiga level analisis yakni analisis teks, kognisi sosial dan relasi kuasa sebagai metode yang tepat untuk membedah isi teks berita jurnalisme bencana seperti yang tertuang berikut ini.

Jurnalisme memiliki kewajiban mengungkapkan realitas itu sebagai bagian dari menjalankan peran sharing of values dan sharing of culture kepada warga masyarakat. Sebagai salah satu media massa terkemuka di Indonesia,
Kompas tak ketinggalan menjadi yang paling utama memberitakan bencana alam gempa bumi yang melanda Kota Padang dan sekitarnya di Sumatra Barat. Bencana yang terjadi pada pukul 17:16:10 WIB tanggal 30 September 2009 dan terjadi pada kekuatan 7,6 Skala Richter di lepas pantai Sumatra Barat, sekitar $50 \mathrm{~km}$ barat laut Kota Padang ini segera menjadi headline di Kompas yang terbit keesokan harinya, tanggal 1 Oktober 2009.

Dari 30 hari terbit pada bulan Oktober 2009 tersebut, tercatat ada 4 berita yang mengangkat tentang konflik pasca bencana gempa, sebagai berikut :

Tabel 1

Tabulasi Berita Kompas Tentang Konflik Pasca Bencana Gempa

\begin{tabular}{|l|l|l|l|}
\hline No & \multicolumn{1}{|c|}{ Edisi } & \multicolumn{1}{|c|}{ Judul } & \multicolumn{1}{|c|}{ Isi Berita Konflik } \\
\hline 1. & $\begin{array}{l}\text { Oktober } \\
2009\end{array}$ & $\begin{array}{l}\text { Kemanusiaan. } \\
\text { Solidaritas dari } \\
\text { Sumut untuk } \\
\text { Warga Padang }\end{array}$ & $\begin{array}{l}\text { Forum Mahasiswa Mitra Kamtibmas Kota } \\
\text { Medan dan Ikatan Mahasiswa Muhammadiyah } \\
\text { IAIN yang menggalang dana bantuan di } \\
\text { bundaran SIB Kota Medan, terlibat bentrok } \\
\text { dengan para pengamen karena para pengamen } \\
\text { merasa lahannya diambil }\end{array}$ \\
\hline 2. & $\begin{array}{l}\text { Oktober } \\
2009\end{array}$ & $\begin{array}{l}\text { Ketua RT 1 RW 16 Kelurahan Kuranji, } \\
\text { Kecamatan Kuranji, Kota Padang meradang di } \\
\text { Berjalan } \\
\text { Lambat } \\
\text { Patamuan }\end{array}$ & $\begin{array}{l}\text { Posko Bantuan Utama Kota Padang. } \\
\text { Penyebabnya belum satupun dana bantuan } \\
\text { untuk 210 Kepala Keluarga yang menjadi } \\
\text { tanggung jawabnya turun. Padahal bantuan } \\
\text { mengalir terus ke Posko Utama. Dia mengaku } \\
\text { kesabarannya sudah habis dan kalau bantuan } \\
\text { takunjung turun juga, barang yang ada di }\end{array}$ \\
\hline
\end{tabular}




\begin{tabular}{|c|c|c|c|}
\hline & & & $\begin{array}{l}\text { posko akan dinaikkan ke mobil karena warga } \\
\text { sudah kelaparan. } \\
\text { Di Posko Bantuan Utama Padang } \\
\text { Pariaman, minggu dini hari terjadi penjarahan } \\
\text { oleh warga yang sampai hari ke empat bencana } \\
\text { alam belum mendapat bantuan apapun. } \\
\text { Warga tidak hanya menjarah di Posko } \\
\text { Bantuan, tetapi juga menghentikan kendaraan } \\
\text { bantuan yang melintas di Kapubaten Padang } \\
\text { Pariaman. }\end{array}$ \\
\hline 3. & $\begin{array}{l}29 \text { Oktober } \\
2009\end{array}$ & $\begin{array}{l}\text { Pasca } \\
\text { Bencana. } \\
\text { Tidak Terima } \\
\text { Bantuan, } \\
\text { Korban Gempa } \\
\text { Unjuk Rasa }\end{array}$ & $\begin{array}{l}\text { Warga Korban Gempa unjuk rasa di } \\
\text { Kota Padang, mereka menyayangkan kebijakan } \\
\text { pemerintah yang hanya memberikan uang lauk- } \\
\text { pauk kepada warga yang rumahnya rusak berat, } \\
\text { padahal tidak sedikit warga yang rumahnya } \\
\text { tidak rusak tapi sedang menderita akibat gempa. } \\
\text { Pengunjuk rasa menyayangkan data } \\
\text { yang tidak valid dan pembagian yang dirasa } \\
\text { tidak adil. }\end{array}$ \\
\hline 4. & $\begin{array}{l}30 \text { Oktober } \\
2009\end{array}$ & $\begin{array}{l}\text { Bantuan } \\
\text { diselewengkan. } \\
\text { Hujan ancam } \\
2.721 \text { Keluarga } \\
\text { Korban Gempa } \\
\text { Jabar }\end{array}$ & $\begin{array}{l}\text { Pelaku penyelewengan bantuan korban gempa } \\
\text { padang adalah pejabat di tingkat kecamatan, } \\
\text { kelurahan hingga dusun. Kebanyakan bantuan } \\
\text { yang diselewengkan adalah bantuan berupa } \\
\text { barang seperti beras dll. }\end{array}$ \\
\hline
\end{tabular}

Sumber : Harian Kompas, Oktober 2009

Dari tabel diatas tampak bahwa

Kompas selama 30 hari pertama pasca gempa, dari total 83 berita tentang gempa hanya terdapat 4 berita tentang konflik pasca bencana. Dari total 4 berita tersebut tampak bahwa pilihan kata yang digunakan harian Kompas cenderung santun dan hanya menampilkan sedikit cuplikan kejadian, dan tidak berusaha menggali lebih lanjut latar belakang dan kelanjutan dari konflik yang muncul.
Dalam level analisis Van Dijk yang paling sentral adalah melihat bagaimana suatu teks di produksi dengan menganalisis kognisi sosial : kesadaran mental wartawan yang membentuk teks tersebut dan bagaimana situasi di sekelilingnya berpengaruh terhadap produksi sebuah teks berita. Analisis Van Dijk berupaya membangun sebuah jembatan yang menghubungkan antara struktur mikro teks dengan struktur 
sosial yang menjadi konteks berita yang disebut sebagai kognisi sosial.

Karena teks yang terdapat dalam suatu berita konflik seringkali bukan merupakan representasi pandangan masyarakat tentang situasi dan kondisi tertentu, tetapi lebih cenderung pada penilaian pribadi wartawan yang menulis berita dan kondisi lingkungan disekitarnya. Hal ini seringkali disebabkan oleh dua hal, yaitu : pertama, kognisi penulis berita yang didominasi pandangan dan nilai-nilai tertentu mengenai kejadian konflik dalam bencana alam, serta pola kerja penulis berita yang cenderung memilah mana berita yang bernilai jual dan mana yang tidak. Artinya, dalam penyebab yang pertama, kecenderungan wartawan mengangkat berita konflik pasca bencana alam lebih dipengaruhi oleh kognisi sosial tersebut yang terbentuk dan terinternalisasi oleh nilai-nilai yang berlaku dalam masyarakat di mana penulis berita tersebut berada. Dalam hal ini, kognisi sosial wartawan disebarkan oleh sebuah lingkungan atau kelompok masyarakat, dan secara khusus hal tersebut dilibatkan dalam praktik memahami, mereproduksi atau merepresentasikan sebuah objek sosial seperti situasi, interaksi, grup atau institusi tertentu. Pengetahuan, sikap dan ideologi yang ada dalam benak penulis berita terbentuk melalui wacana-wacana keseharian seperti percakapan, berita, maupun buku-buku bacaan yang membentuk pengetahuan akan dunia, sikap, ideologi, norma, dan nilai-nilai yang diyakini (Eriyanto, 2001).

William Hendricks (2001) dalam Utsman (2007) menyatakan bahwa konflik adalah sesuatu yang tak terhindarkan dalam kehidupan manusia karena sudah melekat erat dan ada sejalan dengan perubahan sosial yang dialami manusia. Konflik ada untuk dikelola. Dalam hal ini Hendricks mengidentifikasi tahap-tahap konflik yaitu : tahap satu, konflik terjadi dari peristiwa sehari-hari, dan terjadi terus menerus, memerlukan sedikit perhatian, biasanya ditandai dengan timbulnya rasa jengkel yang kemudian akan berubah menjadi masalah. Tahap kedua, konflik ditandai dengan terdapatnya unsur kompetisi dengan "sikap kalah menang". Kekalahan akan memerangkap individu atau kelompok dalam eskalasi konflik yang lebih besar. Konflik tahap ketiga, ditandai dengan munculnya keinginan untuk mencederai atau menghilangkan pihak lawan. 
Dalam penulisan berita konflik pasca bencana alam gempa bumi di Padang lalu, dari hasil analisis elemen tema, bahwa konflik yang terjadi hanya seputar distribusi bantuan yang dianggap tidak adil dan adanya penyelewengan bantuan oleh sejumlah oknum pejabat daerah. Dalam hal ini, Harian Kompas menahan diri untuk tidak mengulas konflik lebih dalam karena dengan pertimbangan posisi Harian Kompas yang berada di tengah-tengah-memegang prinsip humanis pluralis (Sutamat, 2012) dan pengalaman masa lalu yang pernah berurusan dengan pihak pemerintah yang menyebabkan Kompas pernah di bredel dua kali pada tahun 1965 dan tahun 1978 akibat pemberitaan yang cenderung berpihak pada perjuangan mahasiswa membela Tritura pada tahun 1978 dan preseden buruk yang menimpa Kompas yang diberedel pada tahun 1965 akibat kebijakan redaksi yang nyaris berpihak pada PKI. Apalagi saat pembredelan pada awal tahun 1978 itu, Harian Kompas dipaksa untuk menandatangani pernyataan yang salah satunya adalah perjanjian untuk tidak menurunkan berita-berta yang berbau SARA serta hal-hal yang bisa memperuncing konflik (Sularto, 2011).
Pengalaman ini membuat dewan redaksi saat ini sebagai perpanjangan tangan para perintis Harian Kompas menjadi sangat berhati-hati dalam menurunkan berita karena pengambilan keputusan yang tepat menjadi modal terpenting dalam perkembangan Kompas selanjutnya. Pengalaman inilah yang kemudian menyebabkan gaya bahasa Kompas menjadi halus dan netral seperti yang terdapat dalam elemen maksud dan elemen kata ganti. Harian Kompas tidak mau secara langsung menunjuk salah satu pihak yang menyebabkan konflik, jikapun ada sedikit pelabelan, dilakukan secara tersirat dan halus seperti yang tertuang dalam elemen leksikon.

Terlepas dari hal tersebut, dari hasil analisis sosial penelitian ini, konflik mengenai bantuan bencana alam seperti yang terjadi di Sumatra Barat termasuk dalam konflik yang terjadi karena adanya perbedaan aspirasi dalam suatu pihak yang kemudian menimbulkan sikap dan persepsi negatif terhadap salah satu pihak tersebut. Dalam hal ini antara masyarakat yang dilanda bencana alam dan pemerintah setempat. Hal ini bisa diamati dari hasil analisis teks media elemen tema dan latar. 
Bagi Harian Kompas sendiri secara kognisi sosial, konflik yang terdapat dalam masyarakat pasca bencana alam ini diangkat dengan sangat hati-hati dengan menurunkan berita konflik seminimal mungkin. Wartawan Kompas tidak pernah melakukan penulisan yang merupakan hasil tulisan dari pengamatan sendiri mengenai konflik yang terjadi melainkan selalu menurunkan tulisan yang berupa kutipan perkataan dari pihak-pihak yang berkonflik atau dari sumber resmi. Hal ini menjadi jelas bila melihat status Harian Kompas yang 68\% oplahnya berada di Jabodetabek (Sutamat, 2012) .

Kota-kota besar dan satelit yang padat penduduk dengan beragam etnis menjadi sumber penghidupan Kompas, terutama bidang iklan yang menyasar penduduk perkotaan dan Jabodetabek. Sedapat mungkin Kompas memposisikan diri sebagai harian yang netral dan cenderung tidak terkait dengan konflik agar jika ada bahan tulisan mengenai konflik tidak bisa diacu langsung melainkan hanya sekedar rekaman peristiwa yang terjadi langsung. Dengan kata lain, dalam melaporkan berita yang bernuansa konflik, meskipun secara value memiliki nilai berita yang cukup tinggi, wartawan Kompas senantiasa berpegang pada perspektif jurnalisme damai yang menawarkan model pemberitaan konflik yang positif, konstruktif dan etis. Meskipun demikian, bertentangan dengan perspektif jurnalisme damai yang mengangkat berita konflik secara konstruktif, pemberitaan konflik yang diangkat oleh Harian Kompas cenderung dangkal tanpa penggalian lebih dalam terhadap permasalah yang melekat pada konflik tersebut serta tanpa melibatkan sudut pandang dari berbagai pihak, hanya pihak-pihak yang terlibat konflik saja serta tidak adanya pemberitaan mengenai konflik yang diangkat secara berkelanjutan.

Bahasa selalu menjadi masalah dalam berita konflik. Sengaja atau tidak, pers sulit melepaskan diri dari memuat kalimat yang hiperbolis, sarkas, provokatif atau emotif. Kata atau kalimat yang hiperbolis tak jarang membuat pembaca konflik terpengaruh dalam arah yang negatif. Bahasa kompas yang sangat moderat dan terjaga dari kalimat hiperbolis, sarkas, emotif maupun provokatif sehinga berita tentang konflik tidak kemudian menjadi berita yang menyiratkan tensi tinggi (Peleg, 2006 dalam Maisarah, 2012). 
Untuk persoalan bahasa, Kompas sudah menggunakan bahasa yang baik dan santun dalam memberitakan konflik pasca bencana alam yang terkesan ringan dan berimbang. Bahasa yang digunakan Kompas dalam mengulas konflik juga tidak terkesan berusaha memancing emosi pembaca serta tidak menggunakan kalimat-kalimat yang didramatisir, meskipun terlihat untuk kasus konflik lainnya, terkadang Kompas masih menggunakan bahasa yang didramatisir. Bahasa yang baik sendiri sesuai batasan dari Johan Galtung adalah bahasa yang moderat, aktual dan baku. Para pengamat pers kerap mengkritik penggunaan bahasa dalam berita konflik. Bahasa yang hiperbolis, sarkas dan emotif dianggap mampu memprovokasi pembaca dalam arti negatif. Pers dianggap mengabaikan etika dan profesionalitas ketika menggunakan bahasa yang tidak moderat seperti "konflik berkobar" dan lain-lain.

Meski terkadang dinilai terlalu lugas dalam menyampaikan berita konflik pasca bencana, bahasa yang digunakan Kompas sangat jarang menampilkan bahasa yang sarkas dan emotif. Keberadaan proses penyelerasan bahasa oleh tim Penyelaras Bahasa (PB) Kompas sangat mempengaruhi kultur bahasa berita tersebut, karena tim redaksi Kompas sendiri belum memiliki buku putih sebagai pedoman atau standarisasi bahasa dalam penulisan berita (Maisarah, 2012). Untuk membahasakan gaya jurnalisme Kompas ini, Jakob Oetama sebagai pendiri Kompas menyatakan sebagai gaya jurnalisme kepiting, yakni kritik dan keras tetapi sesaat kemudian menarik diri. Gaya jurnalisme ini tidak sertamerta digunakan tanpa alasan. Pentingnya memperhatikan sinyal hatihati dalam jurnalisme Kompas adalah perlu agar terhindar dari kecelakaan yang tidak diharapkan. Alasan utamanya adalah nasib ribuan karyawan yang bernaung di bawah Kompas dan untuk menjaga narasumber. Artinya, bagi sebuah surat kabar, kepercayaan narasumber adalah aset penting karena eksklusifitas sebuah berita bisa diukur dari keberhasilan mewawancarai narasumber-narasumber penting yang belum tentu semua media bisa mewawancarainya. Jurnalisme kepiting juga tercermin dari gaya bahasa Kompas. Gaya bahasa yang hati-hati, seimbang dan disebut sebagai kebosanan yang terawat. Karena itu dalam setiap pemberitaannya, Kompas tidak pernah menggunakan gaya bahasa yang tajam 
dan langsung. Gaya bahasa yang halus dipilih untuk tidak mengesankan sikap keras dan cenderung sembrono, bisa jadi karena Kompas sendiri merupakan salah satu media yang dipandang cukup konvensional dari sudut pandang wartawannya sendiri.

Menarik untuk diamati kemudian, bahwa ternyata, tidak selalu Harian Kompas bersikap "terlalu lembut" dalam mengangkat berita konflik. Sebagai contoh terlihat dalam Maisarah (2012), Harian Kompas bersuara cukup "lantang" dalam mengulas konflik Ahmadiyah. Kesan yang didapatkan adalah, Kompas melakukan sedikit keberpihakan terhadap masyarakat yang menolak keberadaan Ahmadiyah.

Media memiliki beberapa kemungkinan peran ketika memberitakan konflik. Media bisa menjadi agen yang memperparah konflik (ekskalator), meredam konflik (deskalator) atau media hanya berperan sebagai informan yang hanya sebatas memberitakan konflik dengan datar, netral dan moderat (Palluck, 2009). Peran media bagi konflik itu sendiri tergantung pada cara media memandang konflik tercermin dari cara media memposisikan diri di tengah konflik (berpihak atau netral) dan memberitakan konflik (menginformasikan, memperparah, mereduksi).

Namun dalam mengangkat berita konflik pasca bencana alam yang terjadi di Padang kali ini, rupanya Kompas tidak ingin menambah duka masyarakat korban bencana alam dengan pemberitaan yang didramatisasi. Di sisi lain, saat bencana tersebut terjadi, lingkungan seputar dunia pers sedang ramai memberitakan situasi konflik seputar pertentangan antara KPK dan Polri yang ramai diistilahkan dengan tragedi "Cicak vs Buaya" pada awal Agustus 2009. Dunia pers juga sedang fokus mencari berita seputar hasil-hasil pemilu legislatif serta pemilu Presiden yang cukup menyita perhatian. Serta mengamati perkembangan kasus tertangkapnya ketua KPK (Antasari Azhar) saat itu (Juni 2009). Semua hal ini ditenggarai merupakan berita yang lebih menarik untuk dikaji lebih mendalam dari pada sekedar memberitakan konflik yang terjadi pasca bencana alam, sehingga berita yang diangkat dalam pemberitaan Harian Kompas mengenai konflik pasca bencana alam pun cenderung datar.

Menurut pandangan struktural fungsional, media massa memiliki peran 
dalam konflik. Realitas sebagai wacana merupakan pertarungan yang melibatkan pandangan, kepentingan, nilai dan ideologi wartawan dalam sebuah surat kabar. Karena konstruksi realitas sebagai wacana yang diangkat oleh sebuah surat kabar sangat dipengaruhi oleh sistem operasi surat kabar tersebut mulai dari level pengamatan oleh wartawan, penulisan laporan dan kebijakan dewan redaksi hingga faktor-faktor dari luar yang mempengaruhi surat kabar tersebut seperti situasi sosial politik dan pemerintahan, kultur dan etnis masyarakat serta biro iklan.

Menurut Hart (1997), media bukanlah refleksi dari realitas yang sebenarnya, melainkan hasil dari konstruksi. Proses konstruksi realitas tersebut melibatkan proses seleksi isu dan penonjolan berita yang dianggap penting serta menyembunyikam berita yang dianggap tidak penting. Akibatnya media menjadi gatekeeper yang sangat menentukan seperti apa realitas yang ditampilkan di media sehingga isu yang diagendakan media menjadi isu yang dianggap penting oleh khalayak. Khalayak juga merupakan pihak yang pasif, tapi juga mampu memberikan respon terhadap apa yang diberitakan media. Artinya apa yang disampaikan media dapat dimaknai bermacam-macam oleh khalayak.

Terkait berita konflik pasca bencana alam di Harian Kompas ini, pada dasarnya konstruksi berita yang ditampilkan Kompas telah ditata sedemikian rupa agar menjadi sebuah berita yang netral dan aman untuk dikonsumsi oleh khalayak. Penataan ini tidak lepas dari faktor-faktor internal dan eksternal Harian Kompas. Proses konstruksi ini telah melewati kebijakan redaksional yang berfungsi dalam merencanakan, mengorganisasikan dan mengarahkan individu yang terlibat didalamnya sehingga sesuai dengan apa yang menjadi haluan media.

Secara umum, dalam masyarakat pasca bencana, konflik yang muncul adalah konflik vertikal antara pihak pemerintah (atau dalam hal ini satkorlak) dengan masyarakat yang menjadi korban gempa bumi. Permasalahan yang menjadi penyebab konflik berupa konflik mengenai bantuan kemanusiaan, baik berupa uang atau barang.

Menurut Dahrendorf (dalam Usman, 2001) Secara faktor, konflik juga sering diakibatkan oleh terjadinya proses perubahan sosial yang tidak merata dialami oleh masyarakat dalam suatu struktur, serta faktor kepentingan 
yang berbeda yang dapat mengarah pada benturan kepentingan.

Konflik yang terjadi pada masyarakat pasca bencana juga terjadi akibat adanya perubahan sosial yang tidak merata namun dalam hal ini perubahan sosial yang dialami masyarakat pasca bencana lebih pada tekanan dalam kehidupan yang diakibatkan oleh sesuatu hal yang tidak terduga dan di luar jangkauan manusia, sehingga merusak struktur ketahanan masyarakat yang telah terbentuk. Sebagai dampaknya, masyarakat menjadi mudah berkonflik, ditengah tekanan perubahan sosial yang berat ketika ada kepentingan mereka yang berbeda (dalam hal ini pemerintah atau satkorlak) karena adanya kepentingan manusia yang utama yaitu insting untuk bertahan hidup.

Namun ternyata, dibalik terjadinya perubahan sosial yang menyebabkan terjadinya konflik menurut teori Dahrendorf, perbedaan pendapat dalam menyikapi bantuan pasca bencana disikapi masyarakat seperti sebuah perebutan alat produksi. Dalam hal ini, bantuan berupa uang lauk-pauk dapat dianggap sebagai alat produksi untuk melanjutkan kehidupan mereka.
Merujuk pada teori Marx tentang perebutan alat produksi antar kelompok sebagai salah satu sumber konflik. Bedanya konflik yang terjadi adalah konflik vertikal antara pemerintah dan masyarakat. Di sini masyarakat merasa dengan kebijakan pemerintah yang melakukan pembagian uang bantuan lauk pauk yang tidak adil telah mengurangi kesempatan mereka untuk berproduksi kembali.

Konflik yang terjadi pada masyarakat pasca bencana alam Padang juga atas dasar kepentingan alamiah manusia-dalam hal ini perebutan alat produksi untuk bertahan hidup-yang mengalami benturan dengan kelompok lain (pemerintah).

Jika diamati, pola konflik yang terjadi di masyarakat pasca bencana alam Padang ini mirip dengan konflik yang terjadi antara masyarakat dengan pemerintah setempat (RT/Kecamatan) dalam hal pengelolaan pemberian bantuan langsung tunai (BLT) beberapa waktu yang lalu. BLT bagi masyarakat miskin dianggap sebagai salah satu alat produksi dalam mempertahankan hidup dan menjadi kepentingan mereka untuk memperjuangkannya. Sementara itu, konflik sering terjadi akibat pendistribusian bantuan yang tidak 
merata atau pendataan yang sering salah. Konflik yang terkesan kecil ini dapat membesar menjadi aksi protes dan unjuk rasa, hingga aksi teror terhadap pemerintah. Hal ini karena bagi rakyat miskin, jumlah bantuan langsung tunai tersebut sangat besar nilainya.

Demikian juga dengan masyarakat pasca bencana. Ketika suatu masyarakat dilanda bencana, maka status sosial dan strata sosial masyarakat yang terkena bencana menjadi sama dan sejajar. Tidak ada lagi segregasi antara kaya dan miskin. Semua menjadi berkepentingan terhadap bantuan yang dibagikan. Maka tidak heran jika kemudian, bantuan yang bagi sebagian golongan dianggap kecil dan tidak seberapa dapat menjadi sumber konflik yang berpotensi menyulut konflik yang lebih besar lagi.

Hal ini amat relevan dengan pendapat Marx tentang perubahan Mode of production bagian alat produksi (Ritzer dan Goodman, 2008). Dalam kasus ini hanya terdapat dua kelompok golongan dalam masyarakat, yaitu Pemerintah sebagai golongan pemilik sumber daya dan masyarakat sebagai golongan yang tidak mempunyai sumber daya. Perjuangan masyarakat untuk memiliki alat produksi inilah yang pada akhirnya memunculkan kekuatan kolektif masyarakat untuk melakukan aksi protes terhadap pemerintah sebagai kelompok yang dianggap memiliki semua sumber daya. Masyarakat pasca bencana alam yang sudah dalam keadaan tertekan dan putus asa serta kehilangan semua sumber daya yang lalu dihadapkan pada peluang untuk bisa memperoleh kembali sedikit dari alat produksi untuk mempertahankan hidup. Namun ternyata peluang tersebut hilang karena suatu faktor yang tidak masuk akal menurut mereka, hingga menyebabkan timbulnya tindakan kolektif untuk memperjuangkan nasib mereka.

Tidak semua kasus penting-dan menarik-serta layak berita akan muncul dalam pemberitaan media massa. Demikian pula konflik. Ada kalanya suatu konflik luput atau tentunya suatu ketidaksengajaan yang diakibatkan oleh keterbatasan media sehingga melewatkan peristiwa atau konfik tertentu. Namun yang terlihat melalui analisis tema teks berita pada beritaberita konflik pasca bencana yang telah dilakukan terlihat bahwa Kompas, disengaja atau tidak menghindari mengkonfrontasi konflik yang terjadi dengan hanya menampilkan informasi 
mengenai adanya konflik secara sepihak. Aktor-aktor yang terlibat tidak pernah diturunkan bersama dalam satu teks berita sehingga membuat konflik yang terjadi tidak menjadi perhatian.

Pada dasarnya, terbentuknya proses berita dalam suatu media juga tidak terlepas dari kondisi institusional dan organisasional media yang telah diatur dalam kebijakan media tersebut dan oleh berbagai konvensi profesionaldalam hal ini wartawan-dan berkaitan dengan medium menyangkut bahasa dan penggunaan pencitraan karena tingkat informasi referensial yang dikandung oleh suatu teks berita berkaitan dengan kondisi dan keadaan subjektif yang mengatur produksi awal teks tersebut.

\section{KESIMPULAN}

Disadari atau tidak, media mempunyai kekuatan untuk mempengaruhi audiens baik pada ranah kognitif, afektif ataupun behavior. Karena itu sangat penting bagi media massa dalam setiap penulisan bencana alamnya untuk menguasai jurnalisme bencana. Bagaimana sebuah pemberitaan dapat dikonstruksikan sehingga merepresentasikan apa yang terjadi di lapangan tanpa dramatisasi yang berlebihan sehingga mempengaruhi audiens. Pembangunan konstruksi realitas pada masing-masing media berbeda. Pengkonstruksian tergantung pada kebijakan redaksional masingmasing media yang menandakan bagaimana peristiwa dimaknai dan ditampilkan.

Terlihat dari hasil analisis teks berita-berita konflik pasca bencana yang terjadi di Padang, pemberitaan konflik pasca bencana dilakukan oleh Harian Kompas dengan penuh kehati-hatian. Tema berita konflik yang diangkat tidak menyajikan pendapat dari kedua belah pihak yang berkonflik yang disajikan dalam satu teks berita. Penempatannya dibuat terpisah dan tanpa penggalian lebih lanjut tentang konflik yang terjadi dari aktor konflik.

Selain itu sikap netral Kompas yang tidak ingin terlihat merangkul dukungan ataupun mengoposisikan salah satu pihak yang berkonflik menyebabkan berita konflik yang diulas menjadi kurang mendalam penyebab dan aktoraktor yang terlibat di dalamnya.

Dari hasil analisis sosial penelitian ini, konflik mengenai bantuan bencana alam seperti yang terjadi di Sumatra Barat termasuk dalam konflik yang terjadi karena adanya perbedaan aspirasi dalam suatu pihak yang 
kemudian menimbulkan sikap dan persepsi negatif terhadap salah satu pihak tersebut. Dalam hal ini antara masyarakat yang dilanda bencana alam dan pemerintah setempat.

Dari hasil analisis kognisi sosial Harian Kompas, ditemukan bahwa pengalaman masa lalu Harian Kompas yang pernah dibredel dua kali hingga diperbolehkan beroperasi kembali menyebabkan Harian Kompas menerapkan gaya jurnalisme kepiting yang bersikap hati-hati terutama dalam mengulas konflik. Harian Kompas juga menerapkan prinsip humanisme transendental agar bisa diterima semua pihak dan kalangan. Selain itu, keberadaan tim Penyelaras bahasa (BP) yang melakukan penyeragaman bahasa yang dimuat dalam Harian Kompas juga menjadikan gaya bahasa yang digunakan Kompas menjadi halus dan santun.

Wartawan Kompas tidak pernah melakukan penulisan yang merupakan hasil tulisan dari pengamatan sendiri mengenai konflik yang terjadi melainkan selalu menurunkan tulisan yang berupa kutipan perkataan dari pihak-pihak yang berkonflik atau dari sumber resmi. Sedapat mungkin Kompas memposisikan diri sebagai Harian yang netral dan cenderung tidak terkait dengan konflik agar jika ada bahan tulisan mengenai konflik tidak bisa diacu langsung melainkan hanya sekedar rekaman peristiwa yang terjadi langsung. Dengan kata lain, dalam melaporkan berita yang bernuansa konflik, meskipun secara value memiliki nilai berita yang cukup tinggi, wartawan Kompas senantiasa berpegang pada perspektif jurnalisme damai yang menawarkan model pemberitaan konflik yang positif, konstruktif dan etis.

Dalam bencana alam gempa bumi yang terjadi di Padang, Sumatra Barat pada tanggal 30 September 2009 lalu terlihat, konflik yang terjadi adalah konflik vertikal antara masyarakat dengan pemerintah yang disebabkan oleh pendistribusian bantuan yang tidak merata. Meskipun Dahrendorf dalam teori konfliknya menyatakan bahwa secara faktor, konflik juga sering diakibatkan oleh terjadinya proses perubahan sosial yang tidak merata dialami oleh masyarakat dalam suatu struktur, serta faktor kepentingan yang berbeda yang dapat mengarah pada benturan kepentingan, perubahan sosial yang dialami oleh masyarakat pasca bencana lebih karena berupa tekanan yang tidak terduga di luar jangkauan manusia serta adanya faktor kepentingan 
(dengan pihak pemerintah/berkuasa) yang lebih mengarah pada insting untuk bertahan hidup.

Namun ternyata di balik proses perubahan sosial yang menyebabkan konflik seperti pendapat Dahrendorf, konflik lebih disebabkan oleh adanya usaha mendapatkan kembali alat produksi oleh masyarakat karena berubahnya mode of production yang disebabkan oleh bencana alam. Usaha ini mengakibatkan timbulnya konflik vertikal antara pemerintah sebagai pemilik sumber daya dan masyarakat sebagai golongan yang tidak mempunyai sumber daya yang berujung pada tindakan kolektif berupa aksi unjuk rasa menentang kebijakan pembagian bantuan uang lauk pauk oleh pemerintah yang dianggap tidak adil dalam proses pendataannya.

Kompas terkesan berusaha menghindari konflik meskipun tanpa mengupayakan penyelesaian dari suatu masalah secara damai dengan falsafah inti harian ini yaitu humanisme transendental. Pola penulisan jurnalisme Kompas yang seperti ini dipopulerkan dengan istilah jurnalisme kepiting yang cenderung sering melakukan pengujian lapangan sedikit-demi sedikit kemudian menarik diri bila berita yang diturunkan dirasa terlalu keras dan tidak sesuai dengan rezim pemerintahan yang berlaku dan kondisi sosio kultural masyarakat.

Gaya bahasa yang digunakan Harian Kompas dalam mengulas konflik juga tidak terkesan berusaha memancing emosi pembaca serta tidak menggunakan kalimat-kalimat yang didramatisir. Keberadaan proses penyelarasan bahasa oleh tim Penyelaras Bahasa (PB) Kompas sangat mempengaruhi kultur bahasa berita tersebut, karena tim redaksi Kompas sendiri belum memiliki buku putih sebagai pedoman atau standarisasi bahasa dalam penulisan berita.

Sebagai media nasional yang telah teruji melewati berbagai macam rintangan mungkin sebaiknya Kompas bisa lebih kritis lagi dalam menginformasikan berita yang terjadi karena dalam pemberitaan, dampak jangka panjang dari pola yang digunakan akan terihat seperti seperti sebuah kebijakan redaksional.

Penelitian terhadap pemberitaan konflik pasca bencana alam memang tidak bisa terlepas dari penggunaan jurnalisme damai-jurnalisme konflik meskipun tidak selalu menjadi dasar yang utama. Analisis menggunakan teori 
analisis wacana kritis Teun Van Dijk dengan metode tiga level analisis, meskipun diakui sebagai metode analisis terbaik untuk jurnalisme bencana, tetap mempunyai celah jika analisis yang dilakukan tanpa melalui penelitian lapangan, karena level kognisi sosial berkaitan erat dengan para wartawan dan pengelola media yang terlibat dalam produksi berita bencana tersebut.

Pada akhirnya, dari semua hal yang dipaparkan diatas, dalam menuliskan berita konflik pasca bencana alam di Padang ini, Harian Kompas terlihat melakukan komodifikasi berita konflik pasca bencana alam melalui konstruksi beritanya. Berita-berita konflik yang seharusnya diangkat media massa sebagai salah satu wadah untuk menjernihkan konflik, dengan kata lain, dalam menempuh jalan jurnalisme damai, Harian Kompas seharusnya memberitakan konflik pasca bencana alam dengan memuat pendapat kedua belah pihak yang berkonflik dan usulan penyelesaian konflik. Namun karena Harian Kompas hanya terkesan ingin ikut serta dalam memberitakan situasi dan kondisi pasca bencana alam di Padang agar tidak ketinggalan seperti Harian lainnya mengingat reputasi Harian Nasional besar yang dipegang
Kompas, implikasinya pada tingginya oplah Harian Kompas berakibat berita yang diangkat hanya sekedar pemberian informasi sekilas.

\section{DAFTAR PUSTAKA}

Altheide, David L. (1985) Media Power. California : Sage Publication Inc,BeverlyHills,

Eriyanto. 2001. Analisis Wacana, Pengantar Analisis Teks Media. Yogyakarta : Penerbit LkiS.

Hart, Andrew. 1997. Understanding the Media :A Practical Guide. London : Routledge.

Maisarah, Widowati. 2012. Pemberitaan konflik dalam surat kabar Kompas. Analisis isi berita konflik Ahmadiyah, Tarakan dan Papua dalam Surat Kabar Kompas. Pascasarjana Ilmu Komunikasi, Fisipol Universitas Gadjah Mada, tidak di publikasikan.

Millah, Ahmad Shahabul. 2008. Konflik Vertikal di Balik Bantuan Rekonstruksi Rumahbagi Korban gempa bumi. Studi Kasus di Desa Wonokromo, Kecamatan Pleret, Bantul, Daerah Istimewa Yogyakarta. Thesis Sekolah Pasca Sarjana UGM, Tidak dipublikasikan. 
Nazaruddin, Muzayin. 2007. Мепији Jurnalisme Bencana. Yogyakarta : Harian Bernas 10 Mei 2007.

Oliver-Smith, Anthony and Susanna M. Hoffmann. 1999. The Angry Earth, Disaster in Antropological Perspective. New York: Routledge.

Palluck, Elizabeth Levy. Reducing intergroup prejudice using the media : a field experiment in Rwanda dalam Journal Personality and Social Psichology, vol 96 no 3, 574-587, 2009.

Ritzer, George dan Douglas J Goodman. 2008. Teori Sosioligi, dan Teori Sosiologi Klasik Sampai Perkembangan Mutakhir Teori Sosial Postmodern. Yogyakarta : Kreasi Wacana.

Setyarto, Dwiatmodjo Budi. 2012. Konflik kebijakan dan pengetahuan lokal dalam resiko bencana erupsi gunung merapi tahun $2010 \quad d i$ Kinahrejo/Pelemsari, Desa Umbulharjo, kecamatan Cangkringan, Kabupaten Sleman, DIY. Thesis Sekolah Pasca Sarjana Fisipol UGM, tidak di publikasikan.

Soelarto, St. 20120. Syukur Tiada Akhir. Jejak Langkah Jakob Oetama. Jakarta : Penerbit Kompas.
Sukandarrumidi.2010. Bencana Alam dan Bencana Anthropogene. Yogyakarta : Kanisius.

Sutamat, Mamak. 2012. Kompas, Menjadi Perkasa karena kata. Yogyakarta : Galang Press.

Utsman, Sabian. 2007. Anatomi Konflik dan Solidaritas Masyarakat Nelayan.Yogyakarta: Pustaka Pelajar. 